9 Miettinen TA, Tilvis RS, Kesäniemi YA. Serum plant sterols and cholesterol precursors reflect cholesterol absorption and synthesis in volunteers of a randomly selected male population. Am J Epidemiol 1990;131:20-31.

10 Björkhem I, Miettinen TA, Reihner E, Ewerth S, Angelin B, Einarsson K. Correlation between serum levels of some cholesterol precursors and activity of HMG-CoA reductase in human liver. J Lipid Res 1987;28:113743 .

11 Tilvis RS, Miettinen TA. Serum plant sterols and their relation to cholesterol absorption. Am J Clin Nutr 1986;43:92-7.

12 Scandinavian Simvastatin Survival Study Group. Design and baseline results of the Scandinavian simvastatin survival study of patients with stable angina and/or previous myocardial infarction. Am J Cardiol 1993;71:393-400

13 Miettinen TA, Koivisto P. Non-cholesterol sterols and bile acid production in hypercholesterolemic patients with ileal by-pass. In: Paumgartner G, Stiehl A, Gerok W, eds. Bile acids and cholesterol in health and disease. Lancaster, Pennsylvania: MTP, 1983:183-7.

14 Miettinen TA. Cholesterol metabolism during ketoconazole treatment in man. J Lipid Res 1988;29:43-51.

15 Gardner MJ, Altman DG. Confidence interval analysis (CIA): microcomputer program manual and disk. London: BMJ Publishing, 1989.

16 Dixon WJ, ed. BMDP statistical software manual. Vols 1-2. Los Angeles: Berkeley University of California Press, 1992

17 Miettinen TA, Strandberg T, Vanhanen H, Gylling H, for the 4S Group. Non-cholesterol serum sterols in Scandinavian simvastatin survival study. In: Gotto Jr AM, Paoletti R, Smith LC, Catapano AI, Jackson AS, eds. Drugs affecting lipid metabolism. Risk factors and future directions. Dordrecht:
Kluwer Academic Publishers, 1996. (Medical Science Symposium series, No 10:473-6.)

18 Björkhem I, Skrede S. Familial diseases with storage of sterols other than cholesterol: cerebrotendinous xanthomatosis and phytosterolemia. In: Scriver CR, Beaudet AL, Sly WS, Valle D, eds. The metabolic basis of inherited disease. 6th ed. New York: McGraw-Hill, 1989:1283-302.

19 Glueck CJ, Speirs J, Tracy T, Streicher P, Illig E, Vandegrift J. Relationships of serum plant sterols (phytosterols) and cholesterol in 595 hypercholesterolemic subjects, and familial aggregation of phytosterols, cholesterol, and premature coronary heart disease in hyperphytosterolemic probands and their first-degree relatives. Metabolism 1991;40:842-8.

20 Miettinen TA, Kesäniemi YA. Cholesterol absorption: regulation of cholesterol synthesis and elimination and within-population variations of serum cholesterol levels. Am J Clin Nutr 1989;49:629-35.

21 Miettinen TA, Tilvis RS, Kesäniemi YA. Serum cholestanol and plant sterol levels in relation to cholesterol metabolism in middle-aged men. Metabolism 1989;38:136-40.

22 Miettinen TA, Puska P, Gylling H, Vanhanen H, Vartiainen E. Serum cholesterol lowering by sitostanol ester margarine in a mildly hypercholesterolemic random population. N Engl J Med 1995;333:1308-12.

23 Gylling H, Miettinen TA. Effects of inhibiting cholesterol absorption and synthesis on cholesterol and lipoprotein metabolism in hypercholesterolemic non-insulin-dependent diabetic men. J Lipid Res 1996;37:1776-85.

24 Gylling H, Miettinen TA. Sitostanolester added to long term simvastatin treatment of coronary patients with low and high basal cholesterol absorption. Atherosclerosis 1997;134:157.

(Accepted 9 December 1997)

\title{
Risk factors for coronary heart disease and infection with Helicobacter pylori: meta-analysis of 18 studies
}

\author{
John Danesh, Richard Peto
}

Clinical Trial Service Unit and Epidemiological Studies Unit, Nuffield

Department of Clinical Medicine, University of Oxford, Radcliffe Infirmary, Oxford OX2 6HE

John Danesh, Rhodes scholar Richard Peto, professor of medical statistics and epidemiology

Correspondence to: Dr Danesh john.danesh@ balliol.ox.ac.uk

\begin{abstract}
Objective: To find out if chronic infection with Helicobacter pylori is correlated with risk factors for coronary heart disease.

Design: Meta-analysis of 18 epidemiological studies, involving a total of 10000 patients, that measured serum antibody titres to $H$ pylori and risk factors for coronary heart disease. Any study published in any language before 1998 was eligible for inclusion.

Results: Only small absolute differences in body mass index, blood pressure, or haematological risk factors were found between subjects who were seropositive and those who were seronegative. In those who were seropositive body mass index was slightly higher ( 0.37 , SE 0.09) and concentrations of high density lipoprotein cholesterol were slightly lower $(0.032 \mathrm{mmol} / \mathrm{l}, 0.008)$. None of the other differences
\end{abstract} were highly significant.

Conclusion: Previous claims of substantial correlations between $H$ pylori seropositivity and certain vascular risk factors were largely or wholly due to chance or the preferential publication of positive results, or both.

\section{Introduction}

Epidemiological studies have shown that a weakly positive correlation exists between chronic gastric infection with Helicobacter pylori and coronary heart disease. ${ }^{1}$ If this association is causal then infection with $H$ pylori may increase the incidence of coronary heart disease by affecting other vascular risk factors. If there is a non-causal association between $H$ pylori infection and coronary heart disease, then this association must be due to confounding factors. It would be useful to know if infection with $H$ pylori is correlated with body mass index, blood pressure, or haematological factors such as blood lipids, particularly if these variables might also be correlated with coronary heart disease.

When examined individually, the findings of published reports of the possible correlates of $H$ pylori infection seem to have been prone to the effects of chance, or the preferential publication of positive results (publication bias), or both; most studies have had small sample sizes, reported on several different factors, and omitted to perform systematic reviews of the findings of other studies. Systematic reviews of published evidence can increase the amount of data available for analysis; they can also reduce biases that may be introduced through the use of data from small studies that have not been supported by the results of other studies. Such reviews should be less liable to random error and bias than selective emphasis on particular publications would be. We reviewed published studies of the correlations between H pylori seropositivity and variables that might be risk factors for coronary heart disease.

\section{Methods}

Epidemiological and clinical studies in any language published before 1998 that reported on correlations between serum antibody concentrations of $H$ pylori and specific vascular risk factors were identified by searching Medline, relevant reference lists, and gastroenterology and cardiology journals and by discussing studies with the authors of relevant reports. Risk factors examined were systolic blood pressure, diastolic blood pressure, body mass index, plasma viscosity, 
white cell count, and concentrations of total cholesterol, high density lipoprotein cholesterol, triglycerides, fibrinogen, blood glucose, and $\mathrm{C}$ reactive protein. Combinations of key words used in the computer search included Helicobacter pylori, Campylobacter pylori, coronary heart disease, vascular disease, and the vascular risk factors described above. The difference between the mean values of the vascular risk factors in seropositive and seronegative subjects and an estimate of the standard error was obtained from the study or from one of the investigators. Two reports of white cell counts ${ }^{2}{ }^{3}$ and one of blood pressure ${ }^{4}$ were excluded because they did not report measurements of H pylori serum antibody titres. Eighteen eligible studies were identified. ${ }^{5-22}$ The following information was abstracted from each study: the number of people who were seropositive and the number who were seronegative, the difference in the value of the relevant risk factor between subjects who were seropositive and those who were seronegative, and the degree to which adjustments had been made for confounding variables. Studies were classed as having adjusted for age and sex only; for age, sex, and some of the risk factors; or for age, sex, some of the risk factors, and markers of social class. Most of the studies adjusted for more than just age and sex.

In general, studies reported on several vascular risk factors; results are presented for those characteristics that were, in the aggregate, studied in more than 500 subjects. The results from different studies were combined by calculating inverse variance weighted averages of the differences within each study. The variance of a comparison between individuals who were seropositive $\left(\mathrm{n}_{1}\right)$ and those who were seronegative $\left(\mathrm{n}_{2}\right)$ was calculated by multiplying $1 / n_{1}+1 / n_{2}$ by the square of the standard deviation of the relevant variable in the largest study that assessed that variable; for many of the variables this was the study of 2000 people by Murray et al. ${ }^{10} \chi^{2}$ was used to test for heterogeneity.

\section{Results}

The numbers available for analysis varied from 600 (for $\mathrm{C}$ reactive protein) to 10000 (for total cholesterol). Overall there were only small absolute differences between subjects who were seropositive and those who were not (table). Most of these differences were not significant. There were differences in plasma viscosity, blood glucose concentrations, body mass index, and concentrations of high density lipoprotein cholesterol. In those who were seropositive the body mass index $\mathrm{kg} / \mathrm{m}^{2}$ was slightly higher (0.37, SE 0.09 ) and concentrations of high density lipoproteins were slightly lower $(0.032 \mathrm{mmol} / \mathrm{l}, 0.008)$; these were the only differences that were highly significant $(\mathrm{P}<0.0001)$.

There was some evidence of heterogeneity between the six studies that measured white cell counts $^{5} 1213181921 \quad\left(\chi^{2}=18.3, \mathrm{df}=5, \mathrm{P}<0.01\right)$, between the 13 studies in 10 reports that included measurements of diastolic blood pressure ${ }^{691012-1620}\left(\chi^{2}=25.3\right.$, $\mathrm{df}=12, \mathrm{P}=0.01$ ), and between the 11 studies in 10 reports measuring fibrinogen concentrations ${ }^{5} 710$ 13-19 $\left(\chi^{2}=19.6, \mathrm{df}=10, \mathrm{P}=0.04\right)$. There were no strong correlations overall between these three factors and
Correlation between seropositivity for Helicobacter pylori infection and various vascular risk factors in published studies of at least 500 people

\begin{tabular}{|c|c|c|c|c|}
\hline Characteristic & $\begin{array}{c}\text { No } \\
\text { seropositive }\end{array}$ & $\begin{array}{c}\text { No } \\
\text { seronegative }\end{array}$ & $\begin{array}{c}\text { Average (SE) } \\
\text { difference } \\
\text { between } \\
\text { groups† }\end{array}$ & Z ratioł \\
\hline Total cholesterol $(\mathrm{mmol} / \mathrm{l})^{5-16}$ & 5106 & 5274 & $0.04(0.02)$ & 1.5 \\
\hline $\begin{array}{l}\text { Systolic blood pressure } \\
(\mathrm{mm} \mathrm{Hg})^{6791012-1620}\end{array}$ & 4502 & 4795 & $0.9(0.4)$ & $2.1^{*}$ \\
\hline $\begin{array}{r}\text { Diastolic blood pressure } \\
(\mathrm{mm} \mathrm{Hg})^{679} 9^{1012-1620}\end{array}$ & 4502 & 4795 & $0.3(0.3)$ & 1.2 \\
\hline Body mass index $\left(\mathrm{kg} / \mathrm{m}^{2}\right)^{6-8} 1012-1620$ & 4459 & 4739 & $0.37(0.09)$ & $4.2^{* \star * \star}$ \\
\hline $\begin{array}{l}\text { High density lipoprotein cholesterol } \\
(\mathrm{mmol} / /)^{5}\end{array}$ & 4109 & 4316 & $-0.032(0.008)$ & $4.3^{\star \star \star \star}$ \\
\hline Triglyceride $(\mathrm{mmol} / /)^{5-7911-131516}$ & 3431 & 3851 & $0.02(0.04)$ & 0.6 \\
\hline Fibrinogen $(\mathrm{g} / /)^{5} 710$ 13-19 & 2986 & 2228 & $-0.02(0.03)$ & 1.0 \\
\hline Plasma viscosity (mPa.s) ${ }^{10} 18$ & 1270 & 942 & $0.01(0.004)$ & $2.2^{*}$ \\
\hline White cell count $\left(10^{9} / /\right)^{51213181921}$ & 664 & 512 & $0.16(0.11)$ & 1.4 \\
\hline Blood glucose $(\mathrm{mmol} / \mathrm{l})^{5912}$ & 570 & 492 & $0.14(0.06)$ & $2.4^{*}$ \\
\hline $\mathrm{C}$ reactive protein $\left(\mathrm{mg} / \mathrm{l}^{1922}\right.$ & 311 & 292 & $-0.2(0.5)$ & 0.4 \\
\hline
\end{tabular}

†nverse variance weighted average of differences within study (mean in seropositive group minus mean in seronegative group).

$\Varangle$ Ratio of average of differences to SE.

${ }^{*} \mathrm{P}<0.05 ;{ }^{* * * *} \mathrm{P}<0.0001$.

H pylori seropositivity. Most of the heterogeneity was between studies that had first proposed the associations and larger subsequent studies that had failed to confirm the associations.

\section{Discussion}

There have been several claims of strong and significant correlations between chronic H pylori infection and various possible vascular risk factors, such as fibrinogen concentration, ${ }^{5}{ }^{17}$ white cell count, ${ }^{5}$ blood pressure,,$^{23}$ body mass index, ${ }^{23}$ blood lipid concentrations ${ }^{11}$ low alcohol consumption, ${ }^{24}$ or concentrations of $\mathrm{C}$ reactive protein ${ }^{22}$ (which, like the white cell count, may just be a non-specific marker of systemic inflammation). Our review of the published evidence provides results that are more reliable than any individual report. We found no significant correlations between infection with $H$ pylori and blood pressure, white cell count, or concentrations of total cholesterol, fibrinogen, triglycerides, or $\mathrm{C}$ reactive protein. The differences in body mass index and high density lipoprotein cholesterol are both highly significant but, since the absolute differences between subjects who were seropositive and those who were seronegative are small and may have been exaggerated by publication bias, these variables are unlikely to be of much relevance to any association between infection with $H$ pylori and coronary heart disease. The increases in plasma viscosity and blood glucose are only marginally significant; they may be largely or wholly due to chance or publication bias. More importantly, even if they are real, the absolute differences are too small to have a substantial effect on any epidemiological association between chronic infection and coronary heart disease.

Systematic reviews limit spurious associations that may arise from small sample sizes, multiple statistical comparisons, and a selective emphasis on extreme findings in particular studies. Despite our inclusion of studies reported as letters and as abstracts, and of data previously unavailable from published reports, some publication bias may remain; this reinforces our conclusion that correlations found in other studies 
Key messages

- Epidemiological studies suggest that there is a weakly positive association between coronary heart disease and chronic infection with Helicobacter pylori

- A number of reports have also claimed that there are strong correlations between infection with $H$ pylori and an increase in vascular risk factors, such as plasma fibrinogen concentrations

- Meta-analysis of 18 studies that involved 10000 people found no strong correlations between $H$ pylori seropositivity and vascular risk factors; previous findings of the existence of such correlations in small studies were largely or wholly due to chance or to the preferential publication of positive results

between $H$ pylori seropositivity and these vascular risk factors are largely due to chance, or selective publication, or both. The clinical implication is that if there is any relation between chronic H pylor $i$ infection and coronary heart disease, ${ }^{1}$ then it is not likely to be dependent on the risk factors described here.

Colin Baigent and Rory Collins commented helpfully on this paper; Eric Brunner (Whitehall-2 study), Paul Moayyedi (Leeds angiographic study), Steffen J Rosenstock (Glostrup population study), and Mark Woodward (Glasgow MONICA-3 study) provided unpublished numerical details from their studies.

Contributors: JD initiated and performed the study, drafted the manuscript, and is guarantor for the study. RP helped interpret the data and draft the manuscript.

Funding: JD was supported by a Rhodes scholarship and a Frohlich award.

Conflict of interest: None.

1 Danesh J, Collins R, Peto R. Chronic infections and coronary heart disease: is there a link? Lancet 1997;350:430-6.

2 Karttunen T, Niemela S. Increased blood leukocytes in patients with Campylobacter pylori. Ann Int Med 1990;112:232.

3 Karttunen TJ, Niemela S, Kerola T. Blood leukocyte differential in Helicobacter pylori infection. Dig Dis Sci 1996;41:1332-6.

4 Barnes RJ, Uff JS, Dent JC, Gear MWL, Wilkinson SP. Long term follow up of patients with gastritis associated with Helicobacter pylori infection. BrJ Gen Pract 1991;41:286-8.

5 Patel P, Mendall MA, Carrington D, Strachan DP, Leatham E, Molineaux $\mathrm{N}$, et al. Association of Helicobacter pylori and Chlamydia pneumoniae infections with coronary heart disease and cardiovascular risk factors. BMJ 1995;311:711-4.
6 Rosenstock SJ, Andersen LP, Bonnevie O, Jorgensen T. Serum lipids, body-indices, age at menarche, and Helicobacter pylori infection in 1756 Danish women. Gut 1996;39(suppl 3):A62

Wald NJ, Law MR, Morris JK, Bagnall AM. Helicobacter pylori infection and mortality from ischaemic heart disease: negative result from a large, prospective study. BMJ 1997:315:1199-1201.

8 Rathbone BJ, Martin D, Stephens J, Thompson JR, Samani NJ Helicobacter pylori infection does not influence the risk of acute myocardial infarction. Heart 1996;76:308-11.

9 Scragg RKR, Fraser A, Metcalf PA. Helicobacter pylori seropositivity and cardiovascular risk factors in a multicultural workforce. J Epidemiol Community Health 1996;50:578-9.

10 Murray LJ, Bamford KB, O'Reilly DPJ, McCrum EE, Evans AE. Helicobacter pylori infection: relation with cardiovascular risk factors, ischaemic heart disease, and social class. Br Heart J 1995;74:497-501.

11 Niemela S, Karttunen T, Korhonen T, Laara E, Karttunen R, Ikaheimo M, et al. Could Helicobacter pylori infection increase the risk of coronary heart disease by modifying serum lipid concentrations? Heart 1996;75:573-5.

12 Whincup PH, Mendall MA, Perry IJ, Strachan DP, Walker M. Prospective relations between Helicobacter pylori infection, coronary heart disease, and stroke in middle-aged men. Heart 1996;75:568-72.

13 Lip GH, Wise R, Beevers G. Association of Helicobacter pylori with coronary heart disease. $B M J$ 1996;312:250-1.

14 Brunner E, Mendall M, Marmot M. Past or present Helicobacter pylori infection and fibrinogen-a possible link between social class and coronary risk? J Epidemiol Community Health 1995;49:545.

15 McDonagh TA, Woodward M, Morrison C, McMurray J, Tunstall-Pedoe $\mathrm{H}$, Lowe GDO, et al. Lack of independent association of $\mathrm{H}$ pylori and coronary heart disease. Eur Heart J 1997;18:1257-60.

16 Ossei-Gerning N, Moayyedi P, Smith S, Braunholtz D, Wilson JI, Axon ATR, et al. Helicobacter pylori infection is related to atheroma in patients undergoing coronary angiography. Cardiovasc Res 1997;35:120-4.

17 Patel P, Carrington D, Strachan DP, Leatham E, Goggin P, Northfield TC, et al. Fibrinogen: a link between chronic infection and coronary heart disease. Lancet 1994;343:1634-5.

18 Carter AN, Moayyedi P, Catto A, Heppell RM, Axon TR, Grant PJ. The influence of Helicobacter pylori status on circulating levels of the coagulation factors fibrinogen, von Willebrand factor, factor VII, and factor VIII. Helicobacter 1996;1:65-9.

19 Parente F, Maconi G, Imbesi V, Sangaletti O, Poggio M, Rossi E, et al. Helicobacter pylori infection and coagulation in healthy people. $B M J$ 1997;314:1318-9.

20 Mendall MA, Goggin PM, Molineaux N, Levy J, Toosy T, Strachan D, et al. Relation of Helicobacter pylori infection and coronary heart disease. $\mathrm{Br}$ Heart J 1994;71:437-9.

21 Martin de Argila C, Boixeda D, Canton N, Mir N, Gisbert JP, de Rafael L, et al. Leukocyte differential count and Helicobacter pylori infection. Gut 1997;41(suppl 3):A173.

22 Mendall MA, Patel P, Ballam L, Strachan D, Northfield TC. C reactive protein and its relation to cardiovascular risk factors: a population based cross sectional study. BMJ 1996;312:1061-5.

23 Lip GYH, Wise R, Beevers G. Association of Helicobacter pylori infection with coronary heart disease. BMJ 1996;312:250-1.

24 Brenner H, Rothenbacher D, Bode G, Adler G. Relation of smoking and alcohol and coffee consumption to active Helicobacter pylori infection: cross sectional study. BMJ 1997;315:1489-92.

(Accepted 22 December 1997)

\section{Growth hormone as a risk for premature mortality in healthy subjects: data from the Paris prospective study}

Patrick Maison, Beverley Balkau, Dominique Simon, Philippe Chanson, Gabriel Rosselin, Eveline Eschwège

Institut National de la Santé et de la Recherche Médicale Unité 21, Faculté de Médecine Paris Sud, Villejuif, France Patrick Maison, epidemiologist Beverley Balkau research director, Dominique Simon endocrinologist Eveline Eschwège, unit director

continued over

BMJ 1998;316:1132-3
The influence of growth hormone on mortality in adults is well known in conditions such as growth hormone deficiency and acromegaly. ${ }^{12}$ In both diseases the excess mortality is principally from cardiovascular disorders, but the occurrence of malignant disorders has also been reported in acromegaly. ${ }^{2}$ To our knowledge the long term effect of physiological growth hormone on mortality in healthy adults has not been reported.

\section{Subjects, methods and results}

We studied 864 policemen aged 48 to 52 years who did not have cardiovascular disease, diabetes, or glucose intolerance and who had complete data in the Paris prospective study. ${ }^{3}$ They were examined between 1967 and 1973 then followed for mortality until January 1989. The body mass index (weight $(\mathrm{kg}) /\left(\right.$ height $\left.(\mathrm{m})^{2}\right)$ ), ratio of iliac to thigh circumference (a marker of central fat distribution), heart rate, and both diastolic and systolic blood pressures were measured and smoking habits determined. Blood samples were taken at fasting to measure cholesterol and triglyceride concentrations and mean corpuscular volume, and both at fasting and 2 hours after a $75 \mathrm{~g}$ oral glucose tolerance test for concentrations of non-esterified fatty acids, glucose, insulin, and growth hormone with a technique described previously. 